\title{
Novel platensimycin derivatives with herbicidal activity
}

\author{
Fernanda C Moraes, ${ }^{a}$ Elson S Alvarenga, ${ }^{a}{ }^{*}$ Kariny B Amorim, ${ }^{\text {a }}$ Antonio J \\ Demuner $^{\mathrm{a}}$ and Milton E Pereira-Flores ${ }^{\mathrm{b}}$
}

\section{Abstract}

BACKGROUND: Faced with the need to develop herbicides with different modes of action on account of weed resistance to existing herbicides, the sesquiterpene lactones can be the starting point in the search for new bioactive compounds. Lumisantonin and five novel amides have been evaluated against two monocotyledons and three dicotyledons.

RESULTS: An efficient and versatile synthesis of lumisantonin and the five novel amides has been accomplished from readily available $\alpha$-santonin. These compounds were subjected to evaluation for their biological activity against Sorghum bicolor (sorghum), Allium cepa (onion), Cucumis sativus (cucumber), Solanum lycopersicum (tomato) and Bidens pilosa (beggartick). Lumisantonin has inhibited the development of the aerial parts of sorghum and onion by 76 and $67 \%$ at $1000 \mu \mathrm{M}$ respectively. One of the novel amides has prevented the growth of shoots and radicles of sorghum by 80 and $71 \%$ at $1000 \mu \mathrm{M}$ respectively.

CONCLUSION: All of the tested compounds have been found to exhibit promising seed germination inhibition. We can conclude that lumisantonin was on average the most lethal against all plant species evaluated; however, two of the novel amides have exhibited inhibition selectivity against monocotyledons when compared with dicotyledons.

○) 2015 Society of Chemical Industry

Supporting information may be found in the online version of this article.

Keywords: herbicide; amide; lumisantonin; platensimycin; sorghum; onion; beggartick; cucumber

\section{INTRODUCTION}

Bioactive secondary metabolites are natural products that have not been efficiently explored for discovery of new pesticides. Natural products provide inspiration for the development of new products, and sesquiterpene lactones should be cited for their wide biological activity as anti-inflammatory ${ }^{1}$, antigerminative, ${ }^{2}$ phytotoxic ${ }^{3-5}$ and anticancer agents. ${ }^{6}$ Sesquiterpenes are biosynthesised mainly by plants of the family Asteraceae but are also isolated from the fungus Biscogniauxia nummularia, ${ }^{2}$ representing a new promising class of biological agent.

Dehydrocostuslactone (1), costunolide (2) and $\alpha$-santonin (3) are examples of natural sesquiterpene lactones, and $\alpha$-methylene$\alpha$-santonin (4), lumisantonin (5), $\alpha$-methylene-lumisantonin (6), $O$-acetylisophotosantonin (7), $\alpha$-methylene-O-acetylisophotosantonin (8) and photosantonic acid (9) are only a few examples of synthetic derivatives that exhibit some kind of biological activity (Fig. 1). ${ }^{7,8}$

Phospholipase $\left(\mathrm{PLA}_{2}\right)$ are enzymes that hydrolyse glycerophospholipid membranes $(\mathrm{PL})$, releasing fatty acids that are involved in the inflammatory process. Lumisantonin (5), photosantonic acid (9) and $\alpha$-santonin (3) were able to inhibit the effects of PLA from Bothrops jararacussu venom, signifying that the binding site of these inhibitors might be different from the active site of the enzyme. ${ }^{9}$

Alvarenga et al. ${ }^{10}$ described the synthesis and phytotoxic evaluation of several compounds, and O-acetylisophotosantonin (8) exhibited pronounced activity against Sorghum bicolor ( $84.0 \%$ root inhibition), which could be due to the $\alpha, \beta$-unsaturated carbonyl and the acetoxy group. ${ }^{10}$

The $\alpha$-methyl group at the $\gamma$-butyrolactone in lumisantonin (5), $\alpha$-santonin (3) and $O$-acetylisophotosantonin (7) has been converted to a methylidene group by reaction with phenyl selenium chloride, in the presence of lithium diisopropyl amide, followed by treatment of the selenyde with hydrogen peroxide. The $\alpha$-methylidene- $\gamma$-butyrolactone compounds (4), (6) and (8) have displayed significant cytotoxic activities and selectivity against normal cell lines, an important feature towards the development of new drugs against cancer. ${ }^{11}$

Kretschmer et al. ${ }^{12}$ investigated the effects of dehydrocostuslactone (1) and costunolide (2) on cell proliferation, cell cycle, apoptosis and the expression of $A B C$ transporters of three human soft tissue sarcoma cell lines. Dehydrocostuslactone (1) and costunolide (2) exhibited the ability to inhibit the growth of a rare group of malignant tumors, overcoming the expression of the genes ( $A B C$ transporters) associated with genetic diseases and multidrug resistance.

\footnotetext{
Correspondence to: Elson S Alvarenga, Departamento de Química, Universidade Federal de Viçosa, CEP 36570-900, Viçosa, MG, Brazil.

E-mail:elson@ufv.br

a Departamento de Química, Universidade Federal de Viçosa, Viçosa, MG, Brazil

b Departamento de Engenharia Agrícola e Ambiental, Universidade Federal de
} Viçosa, Viçosa, MG, Brazil 

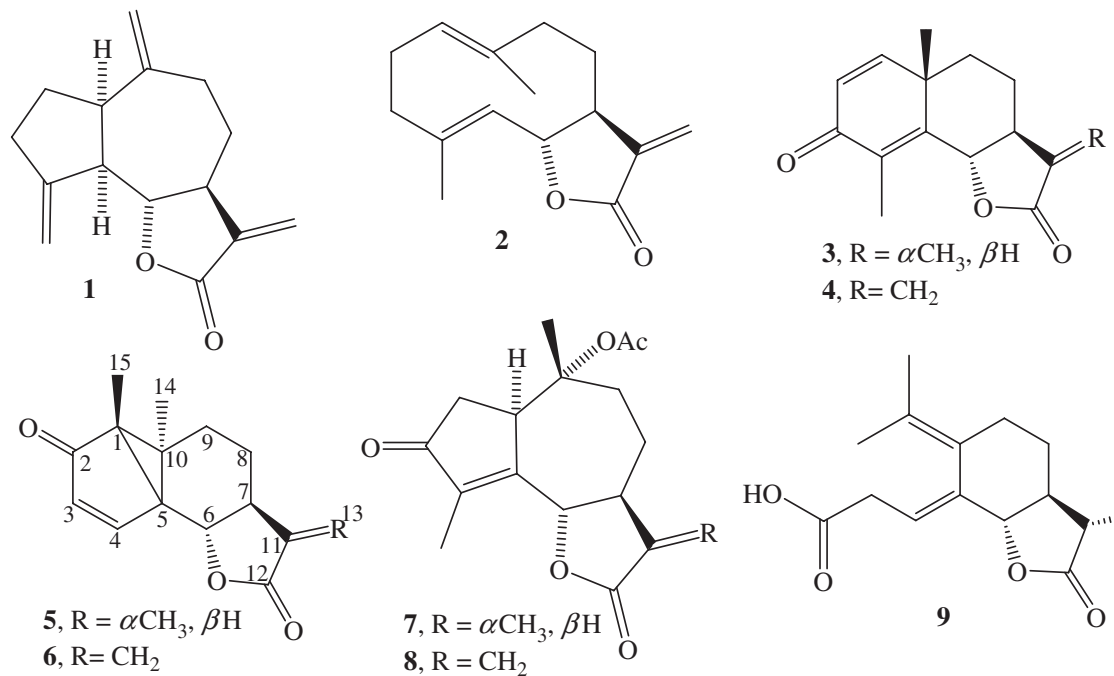<smiles></smiles>

Figure 1. Natural and synthetically modified sesquiterpene lactones.

Bacterial resistance to antibiotics is alarming the world, and the search for novel active principles has been the goal of many research groups throughout the world. Zhang et al. ${ }^{13}$ described the isolation of platensimycin (10) and congeners from Streptomyces platensis. The bactericidal evaluation of the amides revealed the inhibition of bacterial fatty acid synthase by platensimycin (Fig. 2).

Platensimycin (10) is a relatively functionalised molecule, comprising amide, phenol, acid, ketone $\alpha, \beta$-unsaturated and ether functional groups. Herein we report the preparation of amides tethered to a tricycle comprising ketone $\alpha, \beta$-unsaturated and alcohol functional groups. The second aim of this work was to evaluate the phytotoxic activity of amides $\mathbf{1 1}$ to $\mathbf{1 5}$ on several crops in order to assess their structure-activity relationships.

\section{MATERIALS AND METHODS}

\subsection{General procedures}

Reagents and solvents were purified according to the usual procedures described in the literature. ${ }^{14}$ The melting points were determined on an electrothermal digital apparatus and were uncorrected. IR spectra were recorded on a PerkinElmer Spectrum 1000 grating spectrometer (PerkinElmer, Waltham, MA) using sodium chloride liquid film and scanning from 500 to 4000 $\mathrm{cm}^{-1}$. NMR spectra were recorded on a Varian Mercury $300 \mathrm{MHz}$ spectrometer (Varian, Palo Alto, CA). The solvent employed was deuterated chloroform, and the signal of the hydrogen of $\mathrm{CHCl}_{3}$ was used as the reference $(\delta=7.22)$ in the ${ }^{1} \mathrm{H}$ NMR. The signal of the carbon of $\mathrm{CDCl}_{3}$ was used as the reference $(\delta=77)$ in the ${ }^{13} \mathrm{C}$ NMR. GC-MS was conducted with a Shimadzu QP5050A gas chromatograph-mass spectrometer (Shimadzu, Kyoto, Japan) using a glass capillary column $(25 \mathrm{~m} \times 0.25 \mathrm{~mm}) \mathrm{DB}-1$.

\subsection{Synthetic procedures}

\subsubsection{Lumisantonin (5)}

A solution of $\alpha$-santonin 3 (500 mg, $2.0 \mathrm{mmol}$ ) in anhydrous acetonitrile $(300 \mathrm{~mL})$ in a quartz tube was degassed by a flow of nitrogen for $30 \mathrm{~min}$. The solution was irradiated for $4 \mathrm{~h}$ by six low-pressure mercury lamps $(6 \times 15 \mathrm{~W})$. The solvent was removed under vacuum, and the residue was chromatographed in a column packed with silica gel eluting with hexane/ethyl acetate 1:1 $\mathrm{v} / \mathrm{v}$ to afford the title compound as a white solid in $91 \%$ yield. ${ }^{10}$

TLC: $R_{\mathrm{f}} 0.48$ (hexane/ethyl acetate 1:1); $\mathrm{mp} 142.4-143.4{ }^{\circ} \mathrm{C} ; \mathrm{mp}$ (lit.) $147.8-148.9^{\circ} \mathrm{C}^{10} \mathrm{FTIR}\left(\mathrm{KBr}, \mathrm{cm}^{-1}\right) \bar{v}_{\text {max }}: 3944,2993,2883,1774$, $1709,1662,1461,1167,1087,997,896 .{ }^{1} \mathrm{H}$ NMR $\left(300 \mathrm{MHz}_{1} \mathrm{CDCl}_{3}\right)$ $\delta$ (ppm): 1.08 (s, 3H, H14); $1.19(\mathrm{~s}, 3 \mathrm{H}, \mathrm{H} 15) ; 1.23$ (d, 3H, $J=6.9 \mathrm{~Hz}$, $\mathrm{H} 13) ; 1.55-1.68$ (m, 1H, H7); 1.75-1.97 (m, 4H, H8, H9); 2.30 (dq, 1H, $J=13.7, J=6.9 \mathrm{~Hz}, \mathrm{H} 11) ; 3.80(\mathrm{~d}, 1 \mathrm{H}, J=10.9 \mathrm{~Hz}, \mathrm{H} 6) ; 5.98(\mathrm{~d}, 1 \mathrm{H}$, $J=5.7 \mathrm{~Hz}, \mathrm{H} 3) ; 7.57(\mathrm{~d}, 1 \mathrm{H}, J=5.7, \mathrm{H} 4) .{ }^{13} \mathrm{C} \mathrm{NMR}\left(75 \mathrm{MHz}, \mathrm{CDCl}_{3}\right)$ $\delta$ (ppm): 7.3 (C15); 12.4 (C13); 17.0 (C14); 22.3 (C8); 29.5 (C9); 40.3 (C5); 41.0 (C11); 42.6 (C3b); 48.5 (C7); 50.1 (C3a); 77.4 (C6); 131.2 (C1); 157.7 (C2); 178.6 (C12); 206.6 (C3). m/z (\%): 246 ([M] ${ }^{+\bullet}$, $\left.\mathrm{C}_{15} \mathrm{H}_{18} \mathrm{O}_{3}, 43\right), 218(73), 203(37), 190(11), 173(41), 161$ (27), 144 (37), 135 (38), 119 (27), 107 (56), 91 (96), 77 (43), 65 (34), 55 (85), 41 (100).

\subsubsection{General procedure for the preparation of the amides ${ }^{15,16}$}

To a solution of lumisantonin 5 (200 mg, $0.81 \mathrm{mmol}$ ) in dichloromethane $(2 \mathrm{~mL})$ was added the corresponding amine $(4 \mathrm{~mL})$. After stirring for $5 \mathrm{~h}$, a saturated solution of ammonium chloride $(30 \mathrm{~mL})$ was added to the reaction mixture. The mixture was filtered to remove the ammonium chloride precipitated, and the filtrate was transferred to a separating funnel. The organic phase was separated, and the aqueous phase was extracted with dichloromethane $(3 \times 20 \mathrm{~mL})$. The combined organic phases was washed with brine $(20 \mathrm{~mL})$ and dried with anhydrous sodium sulfate. The mixture was filtered and the filtrate was concentrated in the rotary evaporator. The crude product was purified by silica-gel column chromatography to afford the corresponding amides.

(2S)-N-Methyl-2-\{(3aR,3bS,6S,7S)-7-hydroxy-3a,3b-dimethyl-3oxo-3a,3b,4,5,6,7-hexahydro-3H-cyclopenta[1,3]cyclopropa[1,2] benzen-6-yl\}-propanamide (11). Appearance: yellow solid. TLC: $R_{\mathrm{f}}$ 0.49 (ethyl acetate/methanol 6:1); mp 131.0-132.9 ${ }^{\circ} \mathrm{C}$; yield $33 \%$. FTIR $\left(\mathrm{KBr}, \mathrm{cm}^{-1}\right) \bar{v}_{\text {max }}: 3403,3277,3081,2947,2924,1689,1620$, $1543,1409,1318,1079,983,834,702 .{ }^{1} \mathrm{H}$ NMR $\left(300 \mathrm{MHz}, \mathrm{CDCl}_{3}\right) \delta$ (ppm): 1.09 (s, 3H, H14); 1.15 (d, 3H, J=9 Hz, H13); 1.21 (s, 3H, H15); 1.50-1.91 (m, 5H, H4, H4', H5, H5', H6); 2.66 (m, 1H, H2'); 2.83 (d, $\left.3 \mathrm{H}, \mathrm{NCH}_{3}\right) ; 3.63(\mathrm{~s}, 1 \mathrm{H}, \mathrm{OH}) ; 3.69(\mathrm{~d}, 1 \mathrm{H}, J=9.9 \mathrm{~Hz}, \mathrm{H} 7) ; 5.85(\mathrm{~s}, 1 \mathrm{H}$, $\mathrm{NH}) ; 5.89(\mathrm{~d}, 1 \mathrm{H}, J=5.1 \mathrm{~Hz}, \mathrm{H} 2) ; 7.84(\mathrm{~d}, 1 \mathrm{H}, J=5.1 \mathrm{~Hz}, \mathrm{H} 1) .{ }^{13} \mathrm{C} \mathrm{NMR}$ (75 MHz, $\mathrm{CDCl}_{3}$ ) $\delta$ (ppm): 7.6 (C15); 13.1 (C3'); 17.4 (C14); 22.7 (C5); $26.4\left(\mathrm{NCH}_{3}\right) ; 31.2$ (C4); 40.1 (C3a); $41.7\left(\mathrm{C2}^{\prime}\right) ; 44.9$ (C6); 46.8 (C3b); 
<smiles>CC12CC3(C=CC(=O)C1(C)C3)[C@@H](CCC(=O)Nc1c(O)ccc(C(=O)O)c1O)O2</smiles>

Platensimycin (10)

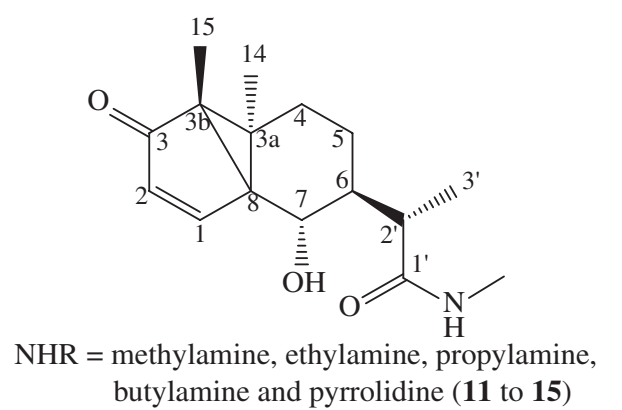

butylamine and pyrrolidine (11 to $\mathbf{1 5}$ )

Figure 2. Structures of the platensimycin and analogues $\mathbf{1 1}$ to 15.

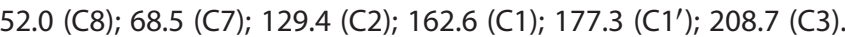
$\mathrm{m} / \mathrm{z}$ (\%): $\left(\mathrm{C}_{16} \mathrm{H}_{23} \mathrm{NO}_{3}\right) 259$ (7), 246 (42), 231 (13), 218 (71), 203 (34), 173 (48), 145 (41), 135 (41), 119 (26), 107 (51), 91 (95), 77 (43), 65 (35), 55 (85), 41 (100), 39 (95).

(2S)-N-Ethyl-2-\{(3aR,3bS,6S,7S)-7-hydroxy-3a,3b-dimethyl-3-oxo$3 a, 3 b, 4,5,6,7$-hexahydro-3H-cyclopenta[1,3]cyclopropa[1,2]benzen6-yl\}-propanamide (12). Appearance: white solid. TLC: $R_{\mathrm{f}} 0.59$ (ethyl acetate/methanol 6:1); $\mathrm{mp} 68.6-69.9{ }^{\circ} \mathrm{C}$; yield 78\%. FTIR $(\mathrm{KBr}$, $\mathrm{cm}^{-1}$ ) $\bar{v}_{\text {max }}: 3487,3412,3237,3071,2971,2881,2754,2141,1695$, $1620,1568,1461,1385,1298,1100,1002,839,654 .{ }^{1} \mathrm{H}$ NMR $(300$ $\left.\mathrm{MHz}, \mathrm{CDCl}_{3}\right) \delta$ (ppm): 1.08-1.15 (m, 8H, H5, H3', H14, $\left.\mathrm{NCH}_{2} \mathrm{CH}_{3}\right)$; $1.20(\mathrm{~s}, 3 \mathrm{H}, \mathrm{H} 15) ; 1.56-1.89\left(\mathrm{~m}, 4 \mathrm{H}, \mathrm{H} 6, \mathrm{H} 4, \mathrm{H} 4^{\prime}, \mathrm{H} 5^{\prime}\right) ; 2.51-2.62(\mathrm{~m}$, $\left.1 \mathrm{H}, \mathrm{H} 2^{\prime}\right) ; 3.21-3.32$ (quint., $\left.2 \mathrm{H}, \mathrm{NCH}_{2}\right) ; 3.68(\mathrm{~d}, 1 \mathrm{H}, J=10,3 \mathrm{~Hz}, \mathrm{H} 7)$; $5.91(\mathrm{~d}, 1 \mathrm{H}, J=5.7 \mathrm{~Hz}, \mathrm{H} 2) ; 6.02(\mathrm{t}, 1 \mathrm{H}, J=5.1 \mathrm{~Hz}, \mathrm{NH}) ; 7.83(\mathrm{~d}, 1 \mathrm{H}$, $J=5.7 \mathrm{~Hz}, \mathrm{H} 1) .{ }^{13} \mathrm{C}$ NMR (75 MHz, $\mathrm{CDCl}_{3}$ ) $\delta$ (ppm): 7.6 (C15); 13.5 $\left(\mathrm{Cl}^{\prime}\right) ; 14.7\left(\mathrm{NCH}_{2} \mathrm{CH}_{3}\right) ; 17.4(\mathrm{C} 14) ; 23.1(\mathrm{C} 5) ; 31.3(\mathrm{C} 4) ; 34.4\left(\mathrm{NCH}_{2}\right)$; 40.1 (C3a); 42.2 (C2'); 45.0 (C6); 46.8 (C3b); 51.9 (C8); 68.7 (C7); 129.4 (C2); 162.6 (C1); 176.4 (C1'); 208.7 (C3). m/z (\%): $\left(\mathrm{C}_{17} \mathrm{H}_{25} \mathrm{NO}_{3}\right)$ 273 (6), 246 (50), 231 (8), 203 (33), 190 (10), 173 (51), 161 (31), 145 (41), 135 (45), 119 (26), 107 (51), 91 (95), 77 (44), 65 (34), 55 (86), 41 (100), 39 (93).

(2S)-N-Propyl-2-\{(3aR,3bS,6S,7S)-7-hydroxy-3a,3b-dimethyl-3oxo-3a,3b,4,5,6,7-hexahydro-3H-cyclopenta[1,3]cyclopropa[1,2]benzen-6-yl\}-propanamide (13). Appearance: white solid. TLC: $R_{\mathrm{f}} 0.65$ (ethyl acetate/methanol 6:1); $\mathrm{mp} 147.5-148.5^{\circ} \mathrm{C}$; yield $86 \%$. FTIR $\left(\mathrm{KBr}, \mathrm{Cm}^{-1}\right) \bar{v}_{\text {max }}: 3383,3294,3073,2945,2871,1682,1637,1539$, $1461,1350,1226,1107,1002,841,757 .{ }^{1} \mathrm{H}$ NMR $\left(300 \mathrm{MHz}, \mathrm{CDCl}_{3}\right)$ $\delta$ (ppm): $0.92\left(\mathrm{t}, 3 \mathrm{H}, J=9 \mathrm{~Hz}, \mathrm{NCH}_{2} \mathrm{CH}_{2} \mathrm{CH}_{3}\right) ; 1.09(\mathrm{~s}, 3 \mathrm{H}, \mathrm{H} 14) ; 1.16$ (d, $\left.3 \mathrm{H}, J=6 \mathrm{~Hz}, \mathrm{H}^{\prime}\right) ; 1.21(\mathrm{~s}, 3 \mathrm{H}, \mathrm{H} 15) ; 1.51$ (sext, $2 \mathrm{H}, J=6 \mathrm{~Hz}$, $\left.\mathrm{NCH}_{2} \mathrm{CH}_{2}\right) ; 1.58-1.88\left(\mathrm{~m}, 5 \mathrm{H}, \mathrm{H} 4, \mathrm{H}^{\prime}{ }^{\prime}, \mathrm{H} 5, \mathrm{H} 5^{\prime}, \mathrm{H} 6\right) ; 2.51-2.63$ (m, $\left.1 \mathrm{H}, \mathrm{H} 2^{\prime}\right) ; 3.21-3.33$ (quint., $\left.2 \mathrm{H}, \mathrm{NCH}_{2}\right) ; 3.67(\mathrm{~d}, 1 \mathrm{H}, J=9 \mathrm{~Hz}, \mathrm{H} 7)$; $5.78(\mathrm{t}, 1 \mathrm{H}, J=6 \mathrm{~Hz}, \mathrm{NH}) ; 5.91(\mathrm{~d}, 1 \mathrm{H}, J=6 \mathrm{~Hz}, \mathrm{H} 2) ; 7.83(\mathrm{~d}, 1 \mathrm{H}$, $J=6 \mathrm{~Hz}, \mathrm{H} 1) .{ }^{13} \mathrm{C}$ NMR $\left(75 \mathrm{MHz}, \mathrm{CDCl}_{3}\right) \delta$ (ppm): 7.9 (C15); 11.6 $\left(\mathrm{NCH}_{2} \mathrm{CH}_{2} \mathrm{CH}_{3}\right) ; 13.5(\mathrm{C} 13) ; 17.7(\mathrm{C} 14) ; 23.0\left(\mathrm{NCH}_{2} \mathrm{CH}_{2}\right) ; 23.1$ (C5); 31.6 (C4); $40.4\left(\mathrm{NCH}_{2}\right) ; 41.5$ (C3a); 42.1 (C2'); 45.3 (C6); 47.1 (C3b); 52.2 (C8); 68.7 (C7); 129.6 (C2); 163.0 (C1); 176.9 (C1'); 209.0 (C3). $\mathrm{m} / \mathrm{z}$ (\%): $\left(\mathrm{C}_{18} \mathrm{H}_{27} \mathrm{NO}_{3}\right) 287$ (6), 259 (10), 246 (43), 203 (36), 190 (10), 173 (41), 161 (26), 145 (41), 135 (33), 119 (25), 107 (45), 91 (87), 77 (40), 65 (31), 55 (75), 41 (100), 39 (85).

(2S)-N-Butyl-2-\{(3aR,3bS,6S,7S)-7-hydroxy-3a,3b-dimethyl-3-oxo$3 a, 3 b, 4,5,6,7-h e x a h y d r o-3 \mathrm{H}$-cyclopenta[1,3]cyclopropa[1,2]benzen6-yl\}-propanamide (14). Appearance: white solid. TLC: $R_{\mathrm{f}} 0.67$ (ethyl acetate/methanol 6:1); $\mathrm{mp} 61.7-62.4{ }^{\circ} \mathrm{C}$; yield $67 \%$. FTIR $(\mathrm{KBr}$, $\left.\mathrm{cm}^{-1}\right) \bar{\nu}_{\text {max }}: 3471,3345,3272,3706,2958,2874,1706,1640,1555$, $1348,1290,1221,1103,999,865,791 .{ }^{1} \mathrm{H}$ NMR $\left(300 \mathrm{MHz}, \mathrm{CDCl}_{3}\right)$ $\delta$ (ppm): 0.92 (t, $3 \mathrm{H}, J=6 \mathrm{~Hz}, \mathrm{NCH}_{2} \mathrm{CH}_{2} \mathrm{CH}_{2} \mathrm{CH}_{3}$ ); 1.09 (s, 3H, H14); $1.16(\mathrm{~d}, 3 \mathrm{H}, J=6 \mathrm{~Hz}, \mathrm{H} 13) ; 1.21(\mathrm{~s}, 3 \mathrm{H}, \mathrm{H} 15) ; 1.32$ (sext, $3 \mathrm{H}, J=6 \mathrm{~Hz}$, $\left.\mathrm{NCH}_{2} \mathrm{CH}_{2} \mathrm{CH}_{2}\right) ; 1.44-1.54\left(\mathrm{~m}, 2 \mathrm{H}, J=6 \mathrm{~Hz}, \mathrm{NCH}_{2} \mathrm{CH}_{2}\right) ; 1.55-1.90$ (m, 6H, H4, H4 $\left.{ }^{\prime}, \mathrm{H} 5, \mathrm{H}^{\prime}, \mathrm{NCH}_{2} \mathrm{CH}_{2} \mathrm{CH}_{2}\right) ; 2.59(\mathrm{dt}, 1 \mathrm{H}, J=6,3 \mathrm{~Hz}, \mathrm{H} 6)$; $3.67(\mathrm{~m}, 2 \mathrm{H}, \mathrm{OH}, \mathrm{H7}) ; 5.74(\mathrm{t}, 1 \mathrm{H}, J=6 \mathrm{~Hz}, \mathrm{NH}) ; 5.92(\mathrm{~d}, 1 \mathrm{H}, J=6 \mathrm{~Hz}$, $\mathrm{H} 2) ; 7.82$ (d, $1 \mathrm{H}, J=6 \mathrm{~Hz}, \mathrm{H} 1) .{ }^{13} \mathrm{C} \mathrm{NMR}\left(75 \mathrm{MHz}, \mathrm{CDCl}_{3}\right) \delta$ (ppm): 7.9 (C15); 13.9 (C13); $14.0\left(\mathrm{NCH}_{2} \mathrm{CH}_{2} \mathrm{CH}_{2} \mathrm{CH}_{3}\right) ; 17.7\left(\mathrm{NCH}_{2} \mathrm{CH}_{2}\right) ; 20.3$ (C14); 23.5 (C5); $31.6\left(\mathrm{NCH}_{2} \mathrm{CH}_{2} \mathrm{CH}_{2}\right) ; 31.8(\mathrm{C} 4) ; 39.6\left(\mathrm{NCH}_{2}\right) ; 40.4$ (C3a); 42.6 (C2'); 45.3 (C6); 47.0 (C3b); 52.1 (C8); 69.0 (C7); 129.7 (C2); 162.8 (C1); $176.7\left(\mathrm{Cl}^{\prime}\right) ; 208.9$ (C3). $\mathrm{m} / \mathrm{z}(\%):\left(\mathrm{C}_{19} \mathrm{H}_{29} \mathrm{NO}_{3}\right) 301$ (2), 273 (18), 259 (6), 246 (13), 218 (9), 203 (26), 173 (44), 145 (47), 107 (25), 91 (80), 77 (39), 65 (21), 55 (76), 41 (100), 39 (60).

(3aR,3bS,6S,7S)-7-Hydroxy-3a,3b-dimethyl-6-[(S)-1-oxo-1-(pyrrolidin-1-yl)propan-2-yl]-3a,3b,4,5,6,7-hexahydro-3H-cyclopenta[1,3] cyclopropa[1,2]benzen-3-one (15). Appearance: white solid. TLC: $R_{\mathrm{f}} 0.35$ (ethyl acetate/methanol 6:1); $\mathrm{mp} 158.3-159.7{ }^{\circ} \mathrm{C}$; yield 79\%. FTIR $\left(\mathrm{KBr}, \mathrm{cm}^{-1}\right) \bar{\nu}_{\text {max }}: 3312,3075,2979,2903,2872,2730$, $1692,1643,1447,1289,1257,1095,1004,836,746,638 .{ }^{1} \mathrm{H}$ NMR (300 MHz, $\left.\mathrm{CDCl}_{3}\right) \delta$ (ppm): $1.07\left(\mathrm{~m}, 6 \mathrm{H}, \mathrm{H}^{\prime}{ }^{\prime}, \mathrm{H} 14\right) ; 1.20(\mathrm{~s}, 3 \mathrm{H}, \mathrm{H} 15)$; 1.71-1.95 (m, 8H, H4, H4' $\left.{ }^{\prime} \mathrm{H} 5, \mathrm{H}^{\prime}, \mathrm{NCH}_{2} \mathrm{CH}_{2}, \mathrm{NCH}_{2} \mathrm{CH}_{2}\right) ; 2.15-2.60$ $(\mathrm{m}, 1 \mathrm{H}, \mathrm{H6}) ; 2.71-2.79\left(\mathrm{~m}, 1 \mathrm{H}, \mathrm{H} 2^{\prime}\right) ; 3.42-3.66\left(\mathrm{~m}, 5 \mathrm{H}, \mathrm{H} 7, \mathrm{NCH}_{2}\right.$, $\left.\mathrm{NCH}_{2}\right) ; 3.90(\mathrm{~s}, 1 \mathrm{H}, \mathrm{OH}) ; 5.89(\mathrm{~d}, 1 \mathrm{H}, J=6, \mathrm{H} 2) ; 7.82(\mathrm{~d}, 1 \mathrm{H}, J=6 \mathrm{~Hz}$, $\mathrm{H} 1) .{ }^{13} \mathrm{C}$ NMR (75 MHz, $\mathrm{CDCl}_{3}$ ) $\delta$ (ppm): 7.6 (C15); 14.5 (C3'); 17.4 (C14); $23.2\left(\mathrm{NCH}_{2} \mathrm{CH}_{2}\right) ; 24.2\left(\mathrm{NCH}_{2} \mathrm{CH}_{2}\right) ; 26.0$ (C5); 31.3 (C4); 40.0 (C3a); 44.1 (C2'); $46.0(\mathrm{C} 6) ; 46.7\left(\mathrm{NCH}_{2}\right) ; 46.8\left(\mathrm{NCH}_{2}\right) ; 51.8(\mathrm{C} 3 \mathrm{~b})$; 69.8 (C8); 69.9 (C7); 129.4 (C2); 162.6 (C1); 175.6 (C1'); 208.6 (C3). m/z (\%): $\left(\mathrm{C}_{19} \mathrm{H}_{27} \mathrm{NO}_{3}\right) 299$ (9), 173 (20), 127 (100), 115 (12), 98 (42), 77 (9), 70 (22), 55 (48), 41 (22).

\section{BIOASSAYS}

The general procedure was as follows. Sorghum bicolor (sorghum), Allium cepa (onion) and Solanum lycopersicum (tomato), 20 seeds per petri dish ( $9 \mathrm{~cm}$ diameter), $5 \mathrm{~mL}$ of test solution, 5 days in the dark, $25{ }^{\circ} \mathrm{C}$ and three replicates of each concentration. The conditions of the bioassay of Bidens pilosa (beggartick) was the same as described above, except that the seeds were maintained for 7 days in the dark. Cucumis sativus (cucumber), 20 seeds per petri dish ( $15 \mathrm{~cm}$ diameter), $8 \mathrm{~mL}$ of test solution, 5 days in the dark, $25{ }^{\circ} \mathrm{C}$ and three replicates of each concentration. The cucumber roots and shoots are very bulky, and therefore their development was hindered when the bioassay was carried out in $9 \mathrm{~cm}$ petri dishes.

The compounds were weighed, dissolved in DMSO and diluted with distilled water to prepare $30 \mathrm{~mL}$ of an aqueous solution containing DMSO $0.3 \% \mathrm{v} / \mathrm{v}$. Half of this solution was used in the bioassays, and the other $15 \mathrm{~mL}$ was diluted with $15 \mathrm{~mL}$ of distilled water containing $0.3 \%$ DMSO v/v to prepare the less concentrated solution. Aqueous DMSO $0.3 \% \mathrm{v} / \mathrm{v}$ was used as a negative control, and the pre-emergence commercial herbicide Dual was used as a positive control. All bioassays were carried out with the solutions 


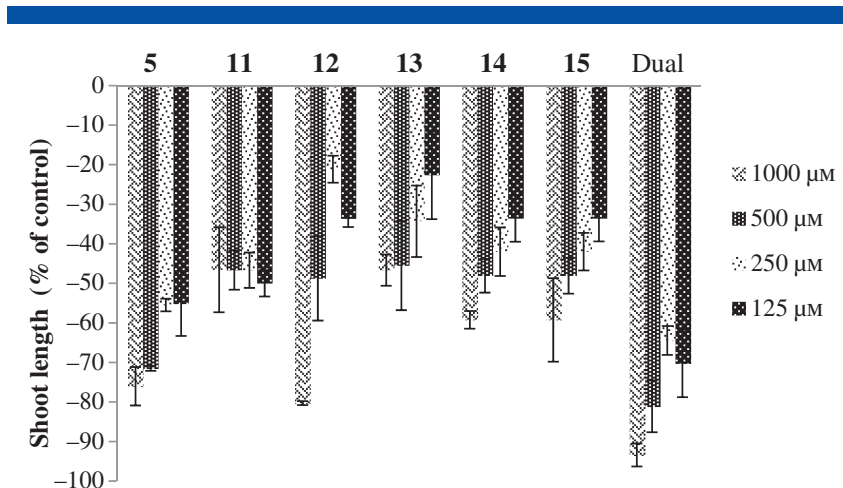

Figure 3. Shoot length of sorghum compared to Dual. Values are expressed as percentage difference from the control.

at concentrations of $1000,500,250,125$ and $50 \mu \mathrm{M}$, except for sorghum, which was not tested at $50 \mu \mathrm{M}$. After the germination period, the seeds were digitally photographed and measured.

The results are presented as percentage differences from the control in bar graphs with standard deviation error bars (Figs 3 to 6). Thus, zero represents the control, positive values represent stimulation of the studied parameter and negative values represent inhibition.

\section{RESULTS AND DISCUSSION}

\subsection{Synthesis}

To prepare compound 5, we utilised a reaction previously described in the literature. ${ }^{10}$ Thus, irradiation of $\alpha$-santonin (3) with six low-pressure mercury lamps, using anhydrous acetonitrile as solvent in a quartz tube, afforded lumisantonin (5) in $91 \%$ yield. The IR spectrum of compound $\mathbf{5}$ showed two strong absorptions at 1774 and $1709 \mathrm{~cm}^{-1}$ due to $\mathrm{C}=\mathrm{O}$ stretching of the lactone and the ketone respectively. The signals at $\delta_{\mathrm{C}} 131.2$ and 157.7 in the ${ }^{13} \mathrm{C}$ NMR confirmed the presence of only one double bond, opposed to the four carbon signals due to the $\mathrm{sp}^{2}$-hybridised carbons observed in the starting material (3).

Compound $\mathbf{5}$ was submitted to reaction with methylamine, ethylamine, propylamine, butylamine and pyrrolidine in dichloromethane to afford amide 11 (33\% yield), 12 (78\% yield), 13 (86\% yield), 14 (67\% yield) and 15 (79\% yield) respectively. ${ }^{15,16}$

The compounds were fully characterised by IR, ${ }^{1} \mathrm{H}$ and ${ }^{13} \mathrm{C}$ NMR spectroscopy, as well as mass spectrometry. As amides $\mathbf{1 1}$ to $\mathbf{1 5}$ presented similar spectrometric data, varying only at the alkyl group bonded to the nitrogen, we decided to describe some of the most important features characterising amide 12. The IR spectra of 12 showed a broad band at $3403 \mathrm{~cm}^{-1}$ due to the hydroxyl stretching of the secondary alcohol. Bands at 3237 and $1620 \mathrm{~cm}^{-1}$ are due to $\mathrm{N}-\mathrm{H}$ and carbonyl stretching of the amide. For obvious reasons the amide derived from pyrrolidine does not have the $\mathrm{N}-\mathrm{H}$ stretching band. The uncommon coupling of $\mathrm{N}-\mathrm{H}$ to $\mathrm{CH}_{2}$ is observed in ${ }^{1} \mathrm{H}$ NMR for amide 12. The amide proton shows up as a triplet at $\delta 6.02$ and the protons of $\mathrm{CH}_{2}$ as a quintet at $\delta 3.27$ due to coupling to $\mathrm{CH}_{3}$ and $\mathrm{N}-\mathrm{H}$.

\subsection{Biological activity}

Sorghum bicolor (Figs 3 and 4). All compounds inhibited aerial growth, with $\mathbf{5}$ and $\mathbf{1 2}$ being the most active compounds, inhibiting 76 and $80 \%$ respectively. This effect reaches a maximum at $1000 \mu \mathrm{M}$, and then decreases with concentration. There is no great difference in root inhibition activity between lumisantonin (5),

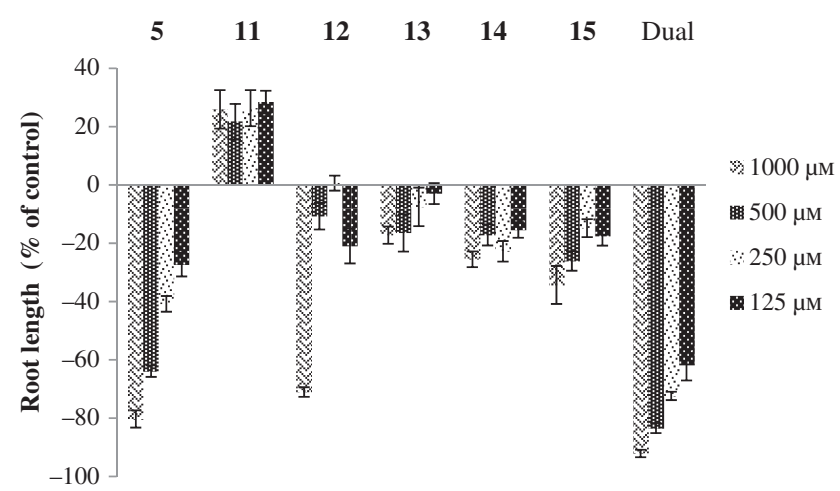

Figure 4. Root length of sorghum compared to Dual. Values are expressed as percentage difference from the control.

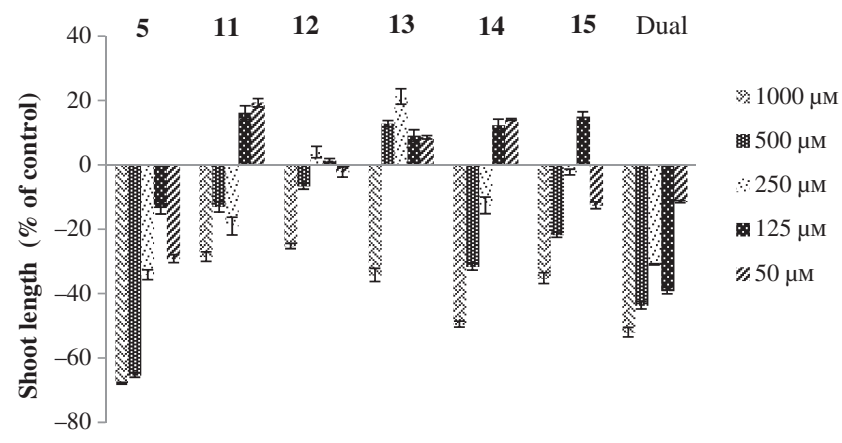

Figure 5. Shoot length of onion compared to Dual. Values are expressed as percentage difference from the control.

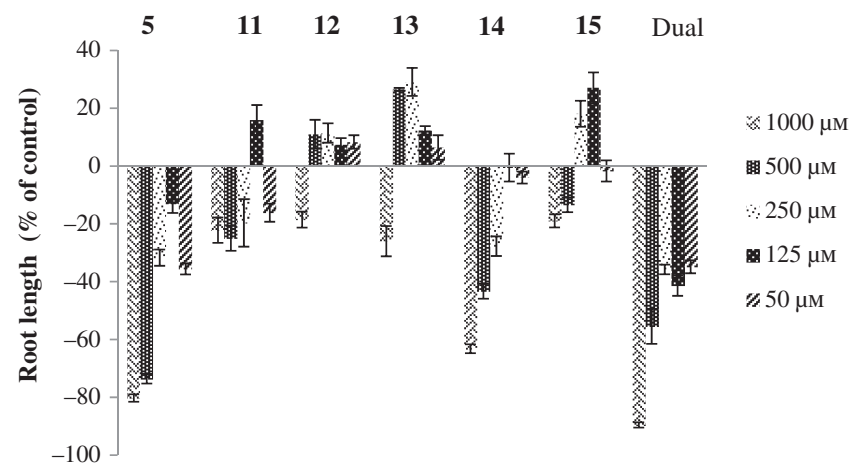

Figure 6. Root length of onion compared to Dual. Values are expressed as percentage difference from the control.

amide 12 and the positive control (Dual) at the highest concentration.

Allium cepa (Fig 5 and 6). Lumisantonin (5) inhibited 65\% of the aerial parts at $500 \mu \mathrm{M}$, while Dual achieved only $43 \%$ inhibition at this concentration. Amide 14 inhibited $49 \%$ of the aerial parts, which is virtually the same as the commercial herbicide, which inhibited $52 \%$ at $1000 \mu \mathrm{M}$. Compounds 5 and $\mathbf{1 4}$ performed best against root development, with 80 and $63 \%$ inhibition respectively.

Cucumis sativus (see supporting information Figs S1 and S2). Apart from the commercial herbicide and lumisantonin (5), which inhibited 56 and $35 \%$ of the aerial parts respectively, all the remaining compounds showed only minor activity. Compound $\mathbf{5}$ was again the most active, inhibiting $60 \%$ of the roots. Compound 
14 was the second most active, but inhibited only $33 \%$ of radicle growth.

Solanum lycopersicum (see supporting information Figs S3 and S4). Compound $\mathbf{5}$ achieved an inhibition of aerial parts similar to that achieved by Dual at $1000 \mu \mathrm{M}$. Compound 13 stimulated the growth of the aerial parts and radicles ( 22 and $92 \%$ respectively) even at the lowest concentration. A study of the interaction of the compounds with the seeds during dormancy and germination has not been carried out in the present work. A review of the progress in the field of seed biology has been greatly aided by molecular approaches utilising mutant and transgenic seeds of Arabidopsis thaliana, tomato and tobacco. ${ }^{17}$

Bidens pilosa (see supporting information Figs S5 and S6). Amides $\mathbf{1 1}$ to $\mathbf{1 5}$ achieved only minor inhibition and stimulation of the shoots and roots of beggartick, while compound $\mathbf{5}$ inhibited completely the development of beggartick seeds at $1000 \mu \mathrm{M}$. The activity of $\mathbf{5}$ is on a par with that of the standard at this concentration. Supporting information Fig. S3 clearly indicates that there is a significant decrease in mean percentage inhibition values with decreasing concentrations.

\section{CONCLUSIONS}

An efficient and versatile synthesis of lumisantonin $\mathbf{5}$ and the five novel amides $\mathbf{1 1}$ to $\mathbf{1 5}$ has been accomplished from the readily available $\alpha$-santonin. These compounds were subjected to evaluation for their biological activity against Sorghum bicolor, Allium cepa, Cucumis sativus, Solanum lycopersicum and Bidens pilosa.

All of the tested compounds have been found to exhibit promising seed germination inhibition activity. Compound $\mathbf{5}$ has shown excellent activity against all plant species evaluated, on a par with the commercial herbicide Dual. Compound $\mathbf{1 2}$ has also shown promising herbicidal activity against sorghum and only minor phytotoxic activity against the remaining species. Therefore, compound 12 shows a certain selectivity towards sorghum that is not observed for either the commercial herbicide or compound $\mathbf{5}$. Compounds $\mathbf{1 1}$ to $\mathbf{1 5}$ had only a slight effect on the development of cucumber and beggartick, while compound 13 stimulated a growth of tomato roots of more than $90 \%$ at all the concentrations evaluated. Compound $\mathbf{1 4}$ was on a par with the standard against onion, but exhibited only minor activity against the dicotyledons (cucumber, tomato and beggartick).

We can conclude that lumisantonin $\mathbf{5}$ is on average the most lethal against all the plant species evaluated; however, compounds 12 and 14 have shown certain inhibition selectivity against monocotyledons when compared with dicotyledons.

\section{ACKNOWLEDGEMENTS}

The authors would like to thank the Brazilian Agencies CNPq, CAPES and FAPEMIG for financial support. We are also grateful to Marcelo Henrique and Vânia Maria for suggestions to improve the manuscript.

\section{SUPPORTING INFORMATION}

Supporting information may be found in the online version of this article.

\section{REFERENCES}

1 Ferreira JRO, Cavalcanti BC, Costa PM, Arantes FFP, Alvarenga ES, Maltha CRA et al., Induction of G2/M arrest, caspase activation and apoptosis by $\alpha$-santonin derivatives in $\mathrm{HL}-60$ cells. Toxicol in Vitro 27:1458-1466 (2013).

2 Amand S, Langenfeld A, Blond A, Dupont J, Nay B and Prado S, Guaiane, sesquiterpenes from Biscogniauxia nummularia featuring potent antigerminative activity. J Nat Prod 75:798-801 (2012).

3 Macías FA, Santana A, Yamahata A, Varela RM, Fronczek FR and Molinillo JMG, Facile preparation of bioactive seco-guaianolides and guaianolides from Artemisia gorgonum and evaluation of their phytotoxicity. J Nat Prod 75:1967-1973 (2012).

4 Macías FA, Santana A, Duran AG, Cala A, Galindo JCG, Galindo JLG et al., Guaianolides for multipurpose molecular design. ACS Symp Ser. Pest Manag Nat Prod 1141:167-188 (2013).

5 Asolkar RN, Cordova-Kreylos AL, Himmel P and Marrone PG, Discovery and development of natural products for pest management. ACS Symp Ser. Pest Manag Nat Prod 1141:17-30 (2013).

6 Khazir J, Singh PP, Mahendhar DR, Hyder I, Shafi S, Sawant SD et al., Synthesis and anticancer activity of novel spiro-isoxazoline and spiro-isoxazolidine derivatives of $\alpha$-santonin. Eur J Med Chem 63:279-289 (2013).

7 Macias FA, Galindo JCG, Castellano D and Velasco RF, Sesquiterpene lactones with potential use as natural herbicide models (I): trans,trans-germacranolides. J Agric Food Chem 47:4407-4414 (1999).

8 Samir AM and Hashinaga AF, Allelopathic potential of two sesquiterpene lactones from Magnolia grandiflora L. Biochem Syst Ecol 35:737-742 (2007).

9 Alvarenga ES, Silva SA, Barosa LCA, Demuner AJ, Parreira AG, Ribeiro RIMA et al., Synthesis and evaluation of sesquiterpene lactone inhibitors of phospholipase A2 from Bothrops jararacussu. Toxicon 57:100-108 (2011).

10 Alvarenga ES, Barbosa LCA, Saliba WA, Arantes FFP and Demuner AJ, Síntese e avaliação da atividade fitotóxica de derivados da $\alpha$-santonina. Quim Nova 32:401-406 (2009).

11 Arantes FFP, Barbosa LCA, Alvarenga ES, Demuner AJ, Bezerra DP, Ferreira JRO et al., Synthesis and cytotoxic activity of $\alpha$-santonin derivatives. Eur J Med Chem 44:3739-3745 (2009).

12 Kretschmer N, Rinner B, Stuendl N, Kaltenegger H, Wolf E, Kunert O et al., Effect of costunolide and dehydrocostus lactone on cell cycle, apoptosis, and $A B C$ transporter expression in human soft tissue sarcoma cells. Planta Med 78:1749-1756 (2012).

13 Zhang C, Ondeyka J, Herath K, Jayasuriya H, Guan Z, Zink DL et al., Platensimycin and platencin congeners from Streptomyces platensis. J Nat Prod 74:329-340 (2011).

14 Perrin DD and Armarego WLF, Purification of Laboratory Chemicals, 3rd edition. Pergamon Press, Oxford, UK, pp. 1-391 (1988).

15 Blay G, Cardona L, Garcia B, Garcia CL and Pedro JR, A non-catalyzed ring-opening aminolysis reaction of sesquiterpene lactones. Tetrahedr Lett 35:931-934 (1994).

16 Blay G, Cardona L, Garcia B, Garcia CL and Pedro JR, Ring-opening aminolysis of sesquiterpene lactones: an easy entry to bioactive sesquiterpene derivatives. Synthesis of (+)-13-cyperone and (-)-eudesma-3,5-diene from santonin. Tetrahedron 52:105 0710518 (1996)

17 Kuceraa B, Cohna MA and Leubner-Metzger G, Plant hormone interactions during seed dormancy release and germination. Seed Sci Res 15:281-307 (2005). 